\title{
Fatty acid profile and in vitro rumen fermentation characteristics of maize silage augmented with canola silage
}

\author{
L. A. Mejía Uribe', I. A. Domínguez Vara', F. Hernández Ruipérez², A. A. Rayas Amor ${ }^{3}$ \& E. \\ Morales Almaráz ${ }^{1 \#}$ \\ ${ }^{1}$ Departamento de Nutrición Animal, Facultad de Medicina Veterinaria y Zootecnia, Universidad Autónoma del Estado de \\ México, Toluca, Estado de México, México \\ ${ }^{2}$ Departamento de Nutrición Animal, Facultad de Veterinaria, Universidad de Murcia, Murcia, España \\ ${ }^{3}$ Departamento de Ciencias de la Alimentación de la Universidad Autónoma Metropolitana Unidad Lerma, Lerma de Villada, \\ Estado de México, C. P. 52005
}

(Submitted 7 January 2020; Accepted 11 December 2020; Published 9 March 2021)

\begin{abstract}
Copyright resides with the authors in terms of the Creative Commons Attribution 4.0 South African Licence.
See: http://creativecommons.org/licenses/by/4.0/za

Condition of use: The user may copy, distribute, transmit and adapt the work, but must recognise the authors and the South African Journal of Animal Science.
\end{abstract}

\begin{abstract}
The objective was to investigate the effect of replacing maize silage (MS) with canola silage (CS) on the chemical composition and fatty acid (FA) profile of total mixed rations (TMR) containing these silages, and on in vitro rumen fermentation and methane production from them. The canola (Brassica napus var. Monty) was cultivated on a small-scale agricultural farm and harvested at 148 days after sowing. Maize silage in a TMR was replaced with $0 \%, 15 \%, 25 \%$, and $35 \%$ CS to make the rations CS0, CS15, CS25, and CS35, respectively. Proximate analyses of the rations were evaluated in a completely randomized design. The results showed that linolenic acid increased linearly with the level of CS, primarily at the expense of linoleic acid. In vitro dry matter digestibility (IVDMD) was similar among treatments. However, in vitro neutral detergent fibre digestibility (IVNDF) decreased linearly $(P<0.05)$ when the CS proportion increased in the TMR. The lowest ammonia nitrogen content $(P<0.05)$ was observed in CS35. The soluble fraction $(A)$ increased $(P<0.05)$ when the CS increased in the TMR from $0 \%$ to $35 \%$. In vitro methane $\left(\mathrm{CH}_{4}\right)$ production was lowest with CS25 and CS35, decreasing $34 \%$ and $23.9 \%$, respectively, compared with CS0. Linolenic acid had a negative correlation with IVNDF $(r=-0.94 ; P$ $<0.05)$. The IVDMD and methane production were positively correlated $(r=0.60)(P<0.05)$. In conclusion, $25 \%$ and $35 \%$ augmentation of MS with CS in a TMR was an important source of linolenic acid (C18:3) and decreased in vitro methane production.
\end{abstract}

Keywords: Brassica napus, fatty acid profile, in vitro digestibility, linolenic acid, total mixed rations

"Corresponding author: emoralesa@uaemex.mx

\section{Introduction}

Canola (Brassica napus) is a crop that shows drought resistance and uses soil water efficiently (SánchezGutiérrez et al., 2018). In Mexico, canola is sown in autumn and winter in rotation after maize to avoid competition with the maize crop for nutrients. Brassica forage is nutritionally valuable for ruminants owing to its high metabolizable energy, crude protein contents, and low level of neutral detergent fibre (NDF) (Barry, 2013, Reta-Sánchez et al., 2015). Another advantage of using brassicas in diets for ruminant animals is that they increase the content of beneficial linolenic acid in milk compared with that produced when the animals are fed MS. Canola fodder can be used by ruminants as conserved forage (hay and silage) or as grazing (Balakhial et al., 2008; Kincaid et al., 2012; Sun et al., 2015; Limón-Mernández et al., 2019). It can be included in a TMR (Kincaid et al., 2012) as a replacement for maize and oat silages (Burbano et al., 2017). However, there is little information about the optimal inclusion level of CS in TMR for small ruminants. 
Some authors indicated a decrease of methane $\left(\mathrm{CH}_{4}\right)$ in vivo from the inclusion in the ration of up to $40 \%$ brassicas on a DM basis (Williams et al., 2016). However, in vitro studies have not reported this effect (LimónHernández et al., 2019). Several feeding strategies have been proposed to mitigate $\mathrm{CH}_{4}$ emissions from enteric fermentation, which include feeds with higher digestibility. Sun et al. (2015) observed a linear decrease of up to $25 \%$ in the in vitro $\mathrm{CH}_{4}$ production after replacing $0 \%, 25 \%, 50 \%, 75 \%$, and $100 \%$ of ryegrass with canola fodder. Canola silage is a good source of linolenic acid (Limón-Hernández et al., 2019), whereas MS provides more linoleic acid (Chilliard et al., 2001). These FAs can promote the synthesis of polyunsaturated fatty acids (PUFAs) such as conjugated linoleic acid (CLA), which is an intermediate in the biohydrogenation of PUFAs, and is desirable for human health (Lock \& Bauman, 2004). Increasing the concentration of linoleic and linolenic acids in the diet for dairy cows, sheep and goats can modify the content of CLA in milk (Lock \& Garnsworthy, 2002; Sanz Sampelayo et al., 2007). Therefore, the objective in this study was to investigate the effects on the chemical composition and FA profile of the diets of replacing MS with three levels of CS, and on in vitro ruminal fermentation and methane production of TMR.

\section{Material and methods}

The study was conducted from May to July 2018 at the Bromatology and Metabolism Laboratory of the Animal Nutrition Department, Universidad Autónoma del Estado de México. The corn crop was cut and chopped, compacted, and sealed in a trench silo that was opened 60 days after sealing. Briefly, the canola crop was harvested and chopped on day 148 after sowing. Two microsilos were used for each of the CS treatments. Sugarcane molasses was diluted in water $(1: 1)$ and added to canola forage to promote a desirable fermentation process. The microsilos consisted of polyvinyl chloride tubes $10 \mathrm{~cm}$ in diameter and $20 \mathrm{~cm}$ in length, packed with $220 \mathrm{~kg}$ DM of silage per cubic metre, sealed with plastic bags and adhesive tape, and kept at room temperature. The microsilos were opened 28 days post incubation and taken to the laboratory for later analysis. The samples of CS were dried at $55{ }^{\circ} \mathrm{C}$ until they lost no further weight, milled (2-mm particle size) and stored at room temperature. The TMR with MS and no CS was the control diet (CS0). As shown in Table 1, three other TMRs were formatted in which a portion of the MS was replaced with $15 \%, 25 \%$, and $35 \%$ of CS (CS15, CS25, CS35, respectively).

Table 1 Chemical composition of total mixed rations with mixtures of canola and maize silages

\begin{tabular}{lrrrr}
\hline & \multicolumn{4}{c}{ Treatments } \\
\cline { 2 - 4 } Ingredients, g/kg & CS0 & CS15 & CS25 & CS35 \\
\hline Canola silage & 0 & 150 & 250 & 350 \\
Maize silage & 500 & 350 & 250 & 150 \\
Maize stover & 100 & 100 & 100 & 100 \\
Soybean meal & 257 & 222 & 202 & 181 \\
Ground sorghum & 20 & 70 & 123 & 184 \\
Wheat bran & 108 & 93 & 60 & 20 \\
Mineral mix & 15 & 15 & 15 & 15 \\
\hline
\end{tabular}

CS0: total mixed ration without canola in the silage, CS15: total mixed ration with $15 \%$ canola silage, CS25: total mixed ration with $25 \%$ canola silage, CS35: total mixed ration with $35 \%$ canola silage

Phosphorus: $120 \mathrm{~g}$, copper $1.33 \mathrm{~g}$, iron: $2 \mathrm{~g}$, magnesium: $10 \mathrm{~g}$, cobalt: $11 \mathrm{mg}$, iodine: $0.080 \mathrm{~g}$, zinc: $4 \mathrm{~g}$, sulfur, $12.5 \mathrm{~g}$, selenium: $0.022 \mathrm{~g}$, calcium: $120 \mathrm{~g}$, salt, $200 \mathrm{~g}$; manganese: $4 \mathrm{~g}$

The analyses of chemical composition, $\mathrm{pH}\left(\mathrm{OAKTON}{ }^{\circledR}\right)$, gas production, IVDMD, organic matter (IVOMD) and in vitro neutral detergent fibre digestibility (IVNDFD) were carried out as described in AOAC (2012), Pell and Schofield (1993) and Theodorou et al. (1994). The in vitro ammonia nitrogen $\left(\mathrm{NH}_{3}-\mathrm{N}\right)$ content was quantified at 72 hours post incubation (Broderick \& Kang, 1980; Theodorou et al., 1994). The in vitro gas production technique was used to determine the kinetics of ruminal fermentation (Theodorou et al., 1994). Each sample 
was assayed in triplicate, and three blanks with ruminal fluid and buffer only were used in each incubation run. Two dairy cows in lactation were used as donors of ruminal fluid, which were fed with a diet based on CS and concentrate. Rumen fluid was extracted with a nasogastric tube filtered in a triple layer of cheesecloth gauze, and homogenized with $\mathrm{CO}_{2}$ for five minutes, then mixed and used as inoculum. The flasks were incubated in a water bath at $39^{\circ} \mathrm{C}$. Gas volume was recorded at 1 to $8,9,12,24,36,40,44,48,52,56,60,72,84$, and 96 hours of incubation, using a Delta pressure transducer (model $8804 \mathrm{HD}$ ). Methane $\left(\mathrm{CH}_{4}\right)$ gas was quantified according to the gas production technique (Theodorou et al., 1994) by measuring the accumulated $\mathrm{CH}_{4}$ concentration in the headspace of the bottles at 24 hours post incubation with an electrochemical methane sensor coupled to a portable analyser (Aeroqual Series 500®). The FA profiles of the TMR were determined (Palmquist \& Jenkins, 2003) and assessed for gas chromatography (Clarus 500 Perkin Elmer chromatograph, equipped with a capillary column of $100 \mathrm{~m} \times 0.25 \mathrm{~mm} \times 0.2 \mu \mathrm{m}$ ) (SULPELCO TM-2560), with nitrogen as carrier gas. The chromatograms were identified according to the retention times of FA methyl ester standards (Supelco37, FAME MIX analytical).

Gas production was fitted to the model described in Jessop and Herrero (1996). The relative gas production (GRY) was calculated as the ratio of DM degradability $(\mathrm{g})$ in vitro to the volume $(\mathrm{ml})$ :

$$
\text { GRY = total gas production (GP } 96 \text { h) / IVDMD. }
$$

Where: GP $96 \mathrm{~h}=$ in vitro gas production at 96 hours ( $\mathrm{ml} / \mathrm{g} \mathrm{DM})$.

Gas yield $\left(\mathrm{GY}_{24}\right)$ was calculated as the volume of gas ( $\mathrm{ml}$ gas / $\mathrm{g} \mathrm{DM}$ ) produced after 24 hours of incubation divided by the amount of IVDMD (Blümmel et al., 1997):

$$
G Y_{24}=\frac{m l g a s / g D M}{i I V D M D}
$$

Short-chain fatty acid (SCFA) concentration was calculated (Getachew et al., 2002) as SCFA (mmol/200 $\mathrm{mg} \mathrm{DM})=0.0222 \mathrm{GP}-0.00425$, where: GP is the 24 hour net gas production ( $\mathrm{ml} / 200 \mathrm{mg} \mathrm{DM})$. Microbial crude protein (MCP) biomass production was calculated (Blümmel et al., 1997) as MCP (mg/g DM) = mg IVDMD - (ml gas $\times 2.2 \mathrm{mg} / \mathrm{ml}$ ), where: $2.2 \mathrm{mg} / \mathrm{ml}$ is a stoichiometric factor, which expresses $\mathrm{mg}$ of the $\mathrm{C}, \mathrm{H}, \mathrm{O}$ required for the production of SCFA gas associated with production of $1 \mathrm{ml}$ of gas.

The effects of the treatments were tested with a general linear model:

$$
Y=\mu+T_{i}+E_{i j}
$$

Where: $Y=$ the response variable,

$\mu=$ general mean,

$\mathrm{T}_{\mathrm{i}}=$ treatment effect, and

$\mathrm{E}_{\mathrm{ij}}=$ experimental error.

The effect of CS inclusion was analysed using orthogonal contrast to evaluate linear and quadratic responses. The Tukey test was applied when significant differences $(P<0.05)$ were observed. Pearson correlations were used to evaluate the relationships between the variables.

\section{Results and Discussion}

A Saanen doe in the eighth week of lactation, which produces $5.3 \mathrm{~kg}$ milk per day, which contains $3.2 \%$ fat and $2.7 \%$ protein, and consumes $3.33 \mathrm{~kg}$ of dry matter, requires $15 \%$ crude protein and $72.3 \%$ total digestible nutrients (NRC, 2007). Table 2 shows the average chemical composition of the diets. Each of these diets would satisfy the requirements for protein but would be slightly deficient in energy for the doe at this particular point in lactation. 
Table 2 Chemical composition $(\mathrm{g} / \mathrm{kg} \mathrm{DM})$ of canola and maize silages and total mixed rations formulated with various proportions of canola silage

\begin{tabular}{|c|c|c|c|c|c|c|}
\hline \multirow{2}{*}{ Variable } & \multicolumn{4}{|c|}{ Treatments } & \multicolumn{2}{|c|}{ Silages } \\
\hline & cso & CS15 & CS25 & CS35 & Canola & Maize \\
\hline DM & $593.04 \pm 1.33$ & $583.43 \pm 0.59$ & $576.93 \pm 0.10$ & $569.61 \pm 0.26$ & $204.2 \pm 0.80$ & $265.8 \pm 3.89$ \\
\hline OM & $934.14 \pm 1.71$ & $929.41 \pm 1.81$ & $924.61 \pm 0.18$ & $923.35 \pm 1.25$ & $892.9 \pm 0.10$ & $949.6 \pm 0.40$ \\
\hline $\mathrm{CP}$ & $164.57 \pm 0.02$ & $165.38 \pm 0.46$ & $165.34 \pm 1.07$ & $164.61 \pm 0.22$ & $141.5 \pm 0.50$ & $47.70 \pm 0.70$ \\
\hline EE & $14.41 \pm 1.67$ & $15.04 \pm 0.63$ & $15.39 \pm 0.04$ & $15.94 \pm 0.05$ & $35.7 \pm 1.50$ & $15.8 \pm 0.30$ \\
\hline NSC & $325.30 \pm 5.40$ & $358.13 \pm 4.80$ & $387.13 \pm 6.50$ & $416.58 \pm 10.80$ & $351.2 \pm 0.80$ & $291.1 \pm 13.3$ \\
\hline NDF & $429.86 \pm 2.00$ & $391.07 \pm 1.58$ & $361.53 \pm 0.12$ & $332.23 \pm 1.19$ & $364.5 \pm 1.90$ & $594.6 \pm 10.2$ \\
\hline ADF & $211.62 \pm 1.03$ & $200.95 \pm 0.43$ & $187.94 \pm 0.56$ & $176.79 \pm 1.06$ & $212.4 \pm 3.20$ & $206.1 \pm 17.0$ \\
\hline$A D L$ & $50.66 \pm 1.53$ & $53.77 \pm 0.17$ & $51.95 \pm 1.00$ & $52.54 \pm 0.12$ & & \\
\hline GE & $4.18 \pm 0.01$ & $4.15 \pm 0.01$ & $4.13 \pm 0.01$ & $4.07 \pm 0.01$ & $4.02 \pm 0.30$ & $4.24 \pm 0.08$ \\
\hline
\end{tabular}

CS0: total mixed ration without canola in the silage, CS15: total mixed ration with 15\% canola silage, CS25: total mixed ration with $25 \%$ canola silage, CS35: total mixed ration with $35 \%$ canola silage, DM: dry matter, OM: organic matter, CP: crude protein, EE: ether extract, NSC: nonstructural carbohydrates, NDF: neutral detergent fibre, ADF: acid detergent fibre, ADL: acid detergent lignin, GE: gross energy

The FA profiles that characterize the treatments are shown in Table 3. The CS inclusion in the TMR had an effect $(P>0.05)$ on the long-chain FA $(>\mathrm{C} 18)$ content. The contents of linolenic acid $(\mathrm{C} 18: 3)$ and heneicosanoic acid $(\mathrm{C} 21: 0)$ increased $(P<0.05)$ with the proportion of $\mathrm{CS}$ in the TMR. On the contrary, as the CS proportion increased in the TMR, its linoleic acid (C18:2) concentration decreased. The contents of lauric (C12:0) $(0.12 \pm 0.04 \mathrm{~g} / 100 \mathrm{~g} \mathrm{FA})$, myristic (C14:0) (0.22 \pm 0.03), and palmitic (C16:0) (18.46 \pm 0.69$)$ FAs were similar $(P>0.05)$ among treatments.

Table 3 Fatty acid profile ( $\mathrm{g} / 100 \mathrm{~g}$ fatty acids) of the total mixed rations with various proportions of canola silage

\begin{tabular}{|c|c|c|c|c|c|c|c|c|}
\hline \multirow{2}{*}{ Fatty acid } & \multicolumn{4}{|c|}{ Treatment (Trt) } & \multirow{2}{*}{ SE } & \multicolumn{3}{|c|}{$P$-values } \\
\hline & CSO & CS15 & CS25 & CS35 & & Trt & Linear & Quadratic \\
\hline Lauric acid & 0.11 & 0.10 & 0.16 & 0.10 & 0.02 & 0.050 & 1.000 & 1.000 \\
\hline Tridecanoic acid & 0.18 & 0.23 & 0.14 & 0.15 & 0.03 & 0.060 & 0.027 & 0.093 \\
\hline Myristic acid & 0.22 & 0.23 & 0.21 & 0.19 & 0.02 & 0.060 & 0.384 & 0.018 \\
\hline Palmitic acid & 18.6 & 18.7 & 18.6 & 17.9 & 0.40 & 0.451 & 1.000 & 0.443 \\
\hline Palmitoleic acid & 0.29 & 0.30 & 0.38 & 0.36 & 0.05 & 0.400 & 0.874 & 0.668 \\
\hline Stearic acid & $2.77^{\mathrm{b}}$ & $2.96^{\mathrm{ab}}$ & $2.94^{\mathrm{ab}}$ & $3.03^{\mathrm{a}}$ & 0.05 & 0.019 & 0.157 & 0.527 \\
\hline Oleic acid & $23.8^{a}$ & $22.2^{\mathrm{ab}}$ & $21.4^{\mathrm{b}}$ & $22.1^{\mathrm{ab}}$ & 0.41 & 0.019 & 0.028 & 0.093 \\
\hline Linoleic acid & $48.5^{\mathrm{a}}$ & $44.6^{\mathrm{b}}$ & $39.6^{c}$ & $36.2^{d}$ & 0.38 & 0.001 & 0.003 & 0.510 \\
\hline Linolenic acid & $5.01^{d}$ & $8.37^{\mathrm{C}}$ & $12.1^{b}$ & $14.0^{\mathrm{a}}$ & 0.38 & 0.001 & 0.001 & 0.278 \\
\hline Heneicosanoic acid & 0 & $1.89^{c}$ & $4.07^{b}$ & $5.38^{\mathrm{a}}$ & 0.12 & 0.001 & 0.001 & 0.737 \\
\hline Others & 0.52 & 0.42 & 0.40 & 0.59 & 0.08 & 0.192 & 0.001 & 0.347 \\
\hline
\end{tabular}

${ }^{a, b, c}$ Within a row, means with a common superscript were not different with probability $P=0.05$

CS0: total mixed ration without canola in the silage, CS15: total mixed ration with 15\% canola silage, CS25: total mixed ration with $25 \%$ canola silage, CS35: total mixed ration with $35 \%$ canola silage 
Fermentation characteristics of the TMR are shown in Table 4. The soluble fraction $(A)$ of the diet increased with the proportion of CS in the TMR. Gas production from the insoluble fraction (B) was lower $(P$ $<0.05)$ in CS25 and CS35 compared with CS0. No significant differences $(P>0.05)$ were detected in the rate $\left(C_{a}\right)$ at which the soluble fraction was digested. The rate $\left(c_{b}\right)$ at which the insoluble fraction was degraded increased with the amount of CS. Lag time was affected linearly $(P<0.05)$, decreasing as the proportion of CS in the TMR increased.

Table 4 Estimates of rumen fermentation parameters for total mixed rations with various proportions of canola silage

\begin{tabular}{|c|c|c|c|c|c|c|c|c|}
\hline \multirow{2}{*}{ Parameter } & \multicolumn{4}{|c|}{ Treatment } & \multirow{2}{*}{ SE } & \multicolumn{3}{|c|}{$P$-value } \\
\hline & cso & CS15 & CS25 & CS35 & & Trt & Linear & Quadratic \\
\hline pH & 6.67 & 6.69 & 6.69 & 6.70 & 0.020 & 0.737 & 1.000 & 1.000 \\
\hline $\mathrm{A}, \mathrm{ml}$ gas/g DM & $28.2^{\mathrm{b}}$ & $37.9^{\mathrm{a}}$ & $36.8^{\mathrm{a}}$ & $40.8^{\mathrm{a}}$ & 1.58 & $<0.001$ & 1.000 & 1.000 \\
\hline $\mathrm{C}_{\mathrm{a}} / \mathrm{h}$ & 0.166 & 0.165 & 0.167 & 0.171 & 0.004 & 0.683 & 0.007 & 0.010 \\
\hline $\mathrm{B}, \mathrm{ml}$ gas/g DM & $232.6^{\mathrm{a}}$ & $232.8^{\mathrm{a}}$ & $223.5^{\mathrm{b}}$ & $222.4^{\mathrm{b}}$ & 3.89 & 0.043 & 0.961 & 0.717 \\
\hline $\mathrm{cb}_{\mathrm{b}} / \mathrm{h}$ & $0.045^{\mathrm{b}}$ & $0.049^{b}$ & $0.053^{\mathrm{a}}$ & $0.056^{\mathrm{a}}$ & 0.001 & $<0.001$ & 0.133 & 0.361 \\
\hline Lag time, hours & $3.19^{a}$ & $2.87^{b}$ & $2.89^{b}$ & $2.99^{\mathrm{ab}}$ & 0.067 & 0.008 & 0.001 & 0.865 \\
\hline IVDMD & 841.9 & 833.1 & 828.7 & 828.4 & 6.36 & 0.423 & 1.000 & 1.000 \\
\hline IVOMD & $906.6^{\mathrm{a}}$ & $924.2^{\mathrm{a}}$ & $869.6^{\mathrm{b}}$ & $896.4^{\mathrm{ab}}$ & 7.18 & $<0.003$ & 0.158 & 0.783 \\
\hline IVNDFD & $649.4^{\mathrm{a}}$ & $617.0^{b}$ & $576.4^{c}$ & $553.9^{c}$ & 5.78 & $<0.001$ & 0.001 & 0.001 \\
\hline RGY & 312.1 & 317.3 & 311.9 & 317.1 & 6.22 & 0.869 & 0.990 & 0.495 \\
\hline GY24 & $198.5^{b}$ & $211.9^{\mathrm{ab}}$ & $221.3^{\mathrm{a}}$ & $220.2^{\mathrm{a}}$ & 4.59 & 0.155 & 0.004 & 0.731 \\
\hline SCFA, mmol/200 mg DMD & $0.742^{b}$ & $0.785^{\mathrm{ab}}$ & $0.825^{\mathrm{a}}$ & $0.807^{\mathrm{a}}$ & 0.015 & 0.014 & 0.002 & 0.948 \\
\hline $\mathrm{MCP}, \mathrm{mg} / \mathrm{g} \mathrm{DMD}$ & $476.7^{\mathrm{a}}$ & $448.2^{\mathrm{ab}}$ & $432.6^{\mathrm{b}}$ & $428.9^{b}$ & 10.01 & 0.021 & 0.008 & 0.610 \\
\hline $\mathrm{NH}_{3}-\mathrm{N}, \mathrm{mg} / \mathrm{dL}$ & $33.1^{\mathrm{a}}$ & $33.7^{\mathrm{a}}$ & $34.3^{\mathrm{a}}$ & $22.6^{\mathrm{b}}$ & 2.41 & $<0.001$ & 1.000 & 1.000 \\
\hline $\mathrm{CH}_{4}, \mathrm{mmol} / \mathrm{g} \mathrm{OMD}$ & 0.346 & 0.263 & 0.227 & 0.264 & 0.034 & 0.115 & 0.142 & 0.707 \\
\hline
\end{tabular}

${ }^{a, b, c}$ Within a row means with a common superscript were not different with probability $P=0.05$

A: gas produced from quickly degradable carbohydrates; $\mathrm{C}_{\mathrm{a}}$ : rate of gas produced from rapidly degradable carbohydrates; $\mathrm{B}$ : gas produced from insoluble fraction; $\mathrm{c}_{\mathrm{b}}$ : rate of gas produced from insoluble fraction; lag: time (hours) before fermentation of insoluble fraction begins; IVDMD: DM degraded at 96 hours (mg/g DM); IVOMD: OMD degraded at 96 hours (mg/g DM); IVNDFD: NDF degraded at 96 hours (mg/g DM); RGY (ml gas 96 h / g IVDMD96 h); GY24: gas yield at 24 hours (mL gas/g DMD); SCFA: short-chain fatty acid; MCP: microbial CP biomass production; NH3-N: ammonia nitrogen at 72 hours post incubation; $\mathrm{CH}_{4}$ : methane at 24 hours post incubation

There were no significant differences $(P>0.05)$ in IVDMD, RGY, and $\mathrm{pH}$. The highest IVOMD and GY24 were observed in CS15, whereas the IVNDFD decreased $(P<0.01) 14.7 \%$ in CS35 compared with the control (Table 4). The CS35 treatment produced the least $(P<0.05) \mathrm{NH}_{3}-\mathrm{N}$ and MCP. Furthermore, CS35 and CS25 reduced in vitro $\mathrm{CH}_{4}$ production by $23.9 \%$ and $34 \%$ at 24 hours post incubation compared with CS0 (Table 4).

Significant estimates of Pearson correlation between TMR characteristics and digestion kinetics are shown in Table 5. C18:2 and C18:3 FAs had strong correlations with IVNDFD and $\mathrm{c}_{\mathrm{b}}$ and slightly weaker relationships with the $\mathrm{B}$ fraction, $\mathrm{pH}$ and the amount of $\mathrm{NH} 3-\mathrm{N}$ that was produced. In vitro $\mathrm{CH}_{4}$ production was correlated negatively with the rates of digestion, but correlated positively with IVDMD $(P<0.05)$.

Various factors influence feed fermentation in the rumen, including the proportion of starch, NDF, and the lignification of the cell wall (Nagani et al., 2000). Beauchemin et al. (2000) stated that the $\left(c_{b}\right)$ fraction is related to the chemical composition and amount of NDF in the diet. This observation may be manifest in the negative correlations of $\left(c_{b}\right)$ with NDF $(r=-0.96)$ and GE $(r=-0.87)$ that were observed in the present study. In vitro dry matter digestibility might indicate the nutritional quality of the diet, with IVDMD higher than $700 \mathrm{~g} / \mathrm{kg}$ DM being 
ideal for ruminants (Chamberlain \& Wilkinson, 2002). In the present study, IVDMD had an average value of $833.07 \pm 6.29 \mathrm{~g} / \mathrm{kg}$ DM when CS was included in the TMR. Kincaid et al. (2012) reported IVDMD of $759 \mathrm{~g} / \mathrm{kg}$ DM in a TMR containing CS (15\% on DM), MS (8.6\%), and alfalfa hay (34\%). IVNDFD decreased with the inclusion of CS in the diet owing to heterogeneity in the cell wall components of brassicas and the bacterial content population (Keim et al., 2018).

Table 5 Significant estimates of Pearson correlation of chemical composition, in vitro digestibility, and fatty acids of total mixed rations with various proportions of canola silage

\begin{tabular}{|c|c|c|c|c|c|c|c|c|}
\hline \multirow{2}{*}{ Variable } & \multicolumn{5}{|c|}{ In vitro gas production and digestibility } & \multicolumn{3}{|c|}{ Fatty acids } \\
\hline & $A$ & $\mathrm{Ca}_{\mathrm{a}}$ & $\mathrm{B}$ & $\mathrm{C}_{\mathrm{b}}$ & IVDDM & C18:1 & C18:2 & $\mathrm{C} 18: 3$ \\
\hline Neutral detergent fibre & & & 0.62 & -0.96 & & & & \\
\hline Acid detergent fibre & & & 0.62 & -0.96 & & & & \\
\hline Nonstructural carbohydrates & & & -0.62 & 0.96 & & & & \\
\hline Gross energy & & & & -0.87 & & & & \\
\hline IVNDFD & 0.77 & & 0.66 & 0.80 & & 0.57 & 0.95 & -0.94 \\
\hline B & & & & -0.52 & & & 0.69 & -0.65 \\
\hline $\mathrm{Cb}_{\mathrm{b}}$ & & & & & & & -0.87 & 0.81 \\
\hline $\mathrm{pH}$ & 0.40 & & -0.43 & & & -0.64 & -0.75 & 0.72 \\
\hline $\mathrm{NH}_{3}-\mathrm{N}$ & & & & & & & 0.62 & -0.60 \\
\hline Methane production at 24 hours & & -0.42 & & -0.55 & 0.60 & & & \\
\hline
\end{tabular}

C18:1, oleic acid; C18:2, linoleic acid, C18:1, linolenic acid; A: gas produced from quickly degradable carbohydrates; $\mathrm{C}_{\mathrm{a}}$ : rate of gas produced from rapidly degradable carbohydrates; $\mathrm{B}$ : gas produced from insoluble fraction; $\mathrm{C}_{\mathrm{b}}$ : rate of gas produced from insoluble fraction; lag: time (hours) before fermentation of insoluble fraction begins; IVDDM: in vitro digestibility of dry matter; IVDNDF: in vitro digestibility of neutral detergent fibre; $\mathrm{NH}_{3}-\mathrm{N}$ : in vitro ammonia nitrogen at 72 hours post incubation, correlations of magnitude greater than 0.40 were significant $(P<0.05)$ and those of magnitude greater than 0.7 were highly significant $(P<0.01)$

There is little information about the effects of CS and methane production. Compared with CS0, the CS25 and CS35 treatments showed $34 \%$ and $23.9 \%$ in vitro $\mathrm{CH}_{4}$ production, respectively. Parven et al. (2005) commented that brassicas possess glucosinolates and tannins that may affect the activity of methanogenic bacteria. However, the mechanisms of action for these compounds remain unknown. On the other hand, Sun et al. (2015) stated that fermentable carbohydrates of canola promote a high synthesis of propionate, which is associated with lower production of hydrogen gas and, consequently, lower production of $\mathrm{CH}_{4}$. LimónHernández et al. (2019) added $0 \%, 1 \%, 2 \%, 3 \%$, and $4 \%$ molasses (a fermentable carbohydrate) to CS and observed decreased $\mathrm{CH}_{4}$ production at 24 hours and 48 hours of digestion. In the present study, similar effects might explain the negative correlation of the $\left(c_{a}{ }^{\prime}\right.$ and $\left(c_{b}\right)$ fractions with in vitro gas production.

The uptake of $\mathrm{NH}_{3}-\mathrm{N}$ by rumen microorganisms is based on protein and carbohydrate degradation. Therefore, the $\mathrm{NH}_{3}-\mathrm{N}$ concentration in the rumen is a good predictor of nitrogen use by rumen microorganisms and its transformation into microbial protein (Hall, 2017). The diet with the highest $\mathrm{NH}_{3}-\mathrm{N}$ uptake was CS35, which resulted in the highest values of MCP (Table 4). The amount and degradation rate of CP can influence the $\mathrm{NH}_{3}-\mathrm{N}$ contents in the rumen (Oh et al., 2008). This degradation of protein that is associated with starch fermentation could explain the differences in $\mathrm{NH}_{3}-\mathrm{N}$ among the treatments in the present study. Ruminal digestion depends on a dynamic sequence of synergic events that influence fermentation products and the production of carbohydrate sources (Gallo et al., 2016). Short-chain fatty acids increased with the inclusion of CS in the TMR, whereas MCP decreased, possibly because of poor synchronization between energy and nitrogen availability. 
The presence of PUFAs in the diet tends to decrease the concentration of $\mathrm{NH}_{3}-\mathrm{N}$ in the rumen. However, it does not affect the flow of digesta to the duodenum, so the impact on the microbial protein synthesis is minimal (Doreau \& Ferlay 1995). In contrast, NDF digestibility is affected by the long-chain FA content in the diet, probably owing to the inhibition of growth of cellulolytic microorganisms (Doreau \& Chilliard, 1997). Indeed, a strong negative correlation $(r=-0.94, P<0.05)$ between IVDNDF and C18:3 was observed in this study. However, similar relationships were not evident with the other long-chain FAs.

The total content of long-chain unsaturated FAs was similar among the CS diets. However, CS35 and CS0 differed notably in their content of $\mathrm{C} 18: 2$ and $\mathrm{C} 18: 3$. Both $\mathrm{C} 18: 2$ and $\mathrm{C} 18: 3$ are essential for the animal, and are precursors of vaccenic acid in the biohydrogenation process (Harfoot \& Hazlewood, 1997). High content of C18:3 could favour the biohydrogenation $(\mathrm{BH})$ synthesis of MUFA such as C18:1 trans and particularly vaccenic acid. Thus, C18:3 is also a precursor of functional components with positive effects on human health (Pariza et al., 2001; Wang et al., 2012). Ruminal pH could affect the activity of cellulolytic bacteria negatively, which could result in a reduction of ruminal $\mathrm{BH}$ of PUFA. Low $\mathrm{pH}$ could affect the production of vaccenic acid and conjugated linoleic acid (CLA) in the rumen (Harfoot \& Hazlewood, 1997). In the present study, the authors observed higher amounts of products from biohydrogenation of PUFA at $\mathrm{pH}$ values between 6.9 and 6.4 in agreement with Troegeler-Meynaider et al. (2003). At lower pH (6.2 - 5.4) a decrease of C18:2 and C18:3 was observed and quantities of C18:1 trans, and CLA decreased (Martin \& Jenkins, 2002). C18:2 and C18:3 are hydrogenated by the same bacteria, and thus similar conditions might affect their BH favourably (Kepler \& Tove, 1967).

Total mixed rations based on MS are typically fed indoors and usually result in milk with reduced FA contents compared with milk from cows in other feeding systems such as TMR plus grazing, grazing only, and TMR plus legume silages (Morales-Almaráz et al., 2010; 2011). One of the main reasons for the improved FA composition of milk was the higher level of dietary $\mathrm{C} 18: 3$, consequent production of vaccenic acid, followed by its desaturation in the mammary gland to produce CLA. Thus, it may be possible to improve milk fat composition by incorporating CS in a TMR for dairy animals.

\section{Conclusion}

Augmenting a TMR with more than 15\% CS affected MCP, IVOMD, and IVNDFD negatively, decreased in vitro methane production, and increased the C18:3 content of the ration. Additional studies are required to evaluate the effect of CS on animal performance and the nutritional quality of the fat in ruminant products.

\section{Acknowledgments}

The authors express their gratitude to Universidad Autónoma del Estado de México for the financial support in the project (4760/2019/CIB) L.A Mejía Uribe was granted a CONACYT fellowship.

\section{Author's Contributions}

LAM-U edited and maintained the data, conducted laboratory analyses, and wrote the original draft of the article; IAD$\mathrm{V}$ designed the research, analysed the data, and reviewed and edited the article; FH reviewed and edited the article; AAR-A provided instrumentation and analysis tools, and reviewed and edited the article; EM-A administered the project, participated in its design, acquired the necessary funding, and reviewed and edited the article.

\section{Conflicts of Interest declaration}

None of the authors has a conflict of interest regarding the content of this manuscript.

\section{References}

AOAC (Association of Official Analytical Chemists), 2012. Official methods of analysis. 19th ed. AOAC, Arlington, VA, USA.

Balakhial A., Naserian, A.A., Herabi Moussavi, A., Eftekhar Shahrodi, F. \& Vali Zadeh, R., 2008. Changes in chemical composition and in vitro DM digestibility of urea and molasses treated whole crop canola silage. J. Anim. Vet. Adv 7,1042-1044.

Barry, T.N., 2013. The feeding value of forage brassica plants for grazing ruminant livestock. Anim. Feed Sci. \& Tech. 181, 15-25. https://doi.org/10.1016/j.anifeedsci.2013.01.012

Beauchemin, K.A., Rode, L.M., Maekawua, M., Morgavi, D.P. \& Kampen, R., 2000. Evaluation of a non-starch polysaccharidase feed enzyme in dairy cows diets. J. Dairy Sci. 83, 543-553. DOI: 10.3168/jds.S00220302(00)74914-9

Blümmel, M., Steingass, H. \& Becker, K., 1997. The relationship between in vitro gas production, in vitro microbial biomass yield an ${ }^{15} \mathrm{~N}$ incorporation and its implications for the prediction of voluntary feed intake of roughages. Br. J. Nutr. 77, 911-921. DOI: https://doi.org/10.1079/BJN19970089

Broderick, G.A. \& Kang, J.H., 1980. Automated simultaneous determinations of ammonia and total amino acids in ruminal fluid and in vitro media. J. Dairy Sci. 63, 64-75. https://doi.org/10.3168/jds.S0022-0302(80)82888-8 
Burbano, M.V.A., López, G.F., Estrada, F.J.G., Sainz, S.P.A. \& Arriaga, J.C.M., 2018. Oat silage grazing dairy cows smallscale systems in the highlands of central Mexico. African J. of Range and Forage Sci. 35 (1), $63-70$. https://doi.org/10.2989/10220119.2018.1473493

Chamberlain, A.T. \& Wilkinson, J.M., 2002. Alimentación de la vaca lechera. Acribia, Zaragoza, España.

Chilliard, Y., Ferlay, A. \& Doreau, M., 2001. Effect of different types of forages, animal fat or marine oil in cows diet on milk fat secretion and composition, especially conjugated linoleic acid (CLA) and polyunsaturated fatty acids. Livest. Prod. Sci. 70, 31-48. https://doi.org/10.1016/S0301-6226(01)00196-8

Doreau, M. \& Ferlay, A., 1995. Effect of dietary lipids on nitrogen metabolism in the rumen: A review. Livest. Prod. Sci. 43, 97-110. https://doi.org/10.1016/0301-6226(95)00041-I

Doreau, M. \& Chilliard, Y., 1997. Digestion and metabolism of dietary fat in farm animals. Brit. J. Nutr. 78, 15-35. DOI: 10.1079/bjn19970132

Gallo, A., Giuberti, G. \& Masoero, F., 2016. Gas production and starch degradability of corn and barley meals differing in mean particle size. J. Dairy Sci. 99, 1-13. https://doi.org/10.3168/jds.2015-10779

Getachew, G., Makkar, H.P.S. \& Becker, K., 2002. Tropical browses: contents of phenolic compounds, in vitro gas production and stoichiometric relationship between short chain fatty acid and in vitro gas production. J. Agric. Sci. 139, $341-352$. https://doi.org/10.1017/S0021859602002393

Hall, B.M. 2017. Nitrogen source and concentration affect utilization of glucosa by mixed ruminal microbes in vitro. J. Dairy Sci. 100, 1-12. https://doi.org/10.3168/jds.2016-12091

Harfoot, C. \& Hazlewood, G.P., 1997. Lipids metabolism in the rumen. In: N. Hobson (ed.) The rumen microbiology ecosystem. Elsevier Applied Science, London, UK. Pp 285-322.

Jessop, N.S. \& Herrero, M., 1996. Influence of soluble components on parameter estimation using the in vitro gas production technique. Anim. Sci. 62, 626-627. DOI:10.1017/S0308229600029986

Keim, J.P., Cabanilla, J., Bolochi, A.O., Pulido, G.R. \& Bertrad, A., 2018. In vitro fermentation and in situ rumen degradation kinetics of summer forage brassica plants. Anim. Prod. Sci. 58 (1), 1-10. https://doi.org/10.1071/AN17534

Kepler, C.R. \& Tove, S.B., 1967. Biohydrogenation of unsaturated fatty acids. 3. Purification and properties of a linoleate delta-12-cis, delta-11-trans- isomerase from Butyrivibrio fibrisolvens. J. Biol. Chem. 242, 5686-5692.

Kincaid, R.L., Johnson, K.A., Michal, J.J., Huisman, A.C., Hulbert, S.H. \& Pan, W.L., 2012. Case study: Production of silage containing biennial canola and peas for use as forage in a dairy ration. Prof. Anim. Scientist 28, $120-124$. https://doi.org/10.15232/S1080-7446(15)30323-5

Limón-Hernández, D., Rayas, A.A.A., Garcia, M.A., Estrada, F.J.G., Nuñez, L.M., Cruz, M.R.G. \& Morales, A.E., 2019. Chemical composition, in vitro gas production, methane production and fatty acids profile of canola silage (Brassica napus) with four levels of molasses. Trop. Anim. Health Prod. 51, 1-6. DOI: 10.1007/s11250-019-01849-7

Lock, A.L. \& Bauman, D.E., 2004. Modifying milk fat composition of dairy cows to enhance fatty acids beneficial to human health. Lipids 39, 1197-1206. DOI: 10.1007/s11745-004-1348-6Lock, A.L. \& Garnsworthy, P.C., 2002. Independent effects of dietary linoleic and linoleinic fatty acids on the conjugated linolenic acid content of cow's milk. Anim. Sci. 74,163-176. https://doi.org/10.1017/S1357729800052334

Martin, S.A. \& Jenkins, T.C., 2002. Factors affecting conjugated linoleic acid and trans-C18:1 fatty acid production by mixed ruminal bacteria. J. Anim. Sci. 80, 3347-3352.DOI: 10.2527/2002.80123347x

Morales-Almaráz, E., de la Roza-Delgado, B., González, A., Soldado, A., Rodríguez, M.L., Peláez, M., Vicente, F., 2011. Effect of feeding system on unsaturated fatty acid levels in milk of dairy cows. Renew. Agric. Food Syst. 26, $224-229$. https://doi.org/10.1017/S1742170511000019

Morales-Almaráz, E., Soldado, A., González, A., Martínez-Fernández, A., Domínguez-Vara I. A., De la Rosa-Delgado, B. \& Vicente, F., 2010. Improving the fatty acid profile of dairy cow milk by combining grazing with feeding of total mixed ration. J. Dairy Res. 77, 225-230. DOI: 10.1017/S002202991000004X

Nagani, S., Herrero, M. \& Jessop, N.S., 2000. The effect of fermentable nitrogen availability on in vitro gas production and degradability NDF. Anim. Feed Sci. Tech. 87, 241-251. https://doi.org/10.1016/S0377-8401(00)00194-2

NRC (National Research Council), 2007. Nutrient requirements of small ruminants: Sheep, goats, cervids and New World camelids. The National Academy of Science, Washington DC, USA.

Oh, Y., Kim, J., Kim, K., Choi, C., Kang, S., Nam, I., Kim, D., Song, M., Kim, C. \& Park, K., 2008. Effects of level and degradability of dietary protein on ruminal fermentation and concentrations of soluble non-ammonia nitrogen in ruminal and omasal digesta of Hanwoo steers. Asian Australas. J. Anim. Sci. 21, $392-403$. DOI: 10.5713/ajas.2008.70342

Palmquist, D.L. \& Jenkins, T.C., 2003. Challenges with fats and fatty acid methods. J. Anim. Sci. 81, 3250-3254. DOI: $10.2527 / 2003.81123250 x$

Pariza, M.W., Park, Y. \& Cook, M.E., 2001. The biologically active isomers of conjugated linoleic acid. Prog. Lipid Res. 40, 283-298. DOI: 10.1016/s0163-7827(01)00008-x

Parven, I., Threadgill, M.D. Moorby, J.M. \& Winter, A., 2010. Oxidative phenols in forage crops containing polyphenol oxidase enzymes. J. Agri. Food Chem. 58, 1371-1382. https://doi.org/10.1021/jf9024294

Pell, A.N. \& Schofield, P., 1993. Computerized monitoring of gas production to measure forage digestion in vitro. J. Dairy Sci. 76, 1063-1073.https://doi.org/10.3168/jds.S0022-0302(93)77435-4 
Reta-Sánchez, D.G., Serrato, C.J.S., Quiroga, G.H.M., Gaytán, M.A. \& Figueroa, V.U., 2015. Forage yield and chemical composition of canola (Brassica napus L.) as affected by sowing methods. Grass Forage Sci. 71(2), $281-290$. https://doi.org/10.1111/gfs.12174

Sánchez-Gutiérrez, R.A., Espinoza-Canales, A., Muro-Reyes, A. \& Gutiérrez-Bañuelos H., 2018. Growth and production of autumn-winter canola (Brassica napus L.) forage in Zacatecas, México. Rev. Fitotec. Mex. 41(2), 211216.https://doi.org/10.35196/rfm.2018.2.211-216 (In Spanish).

Sanz Sampelayo, M.R., Chilliard, Y., Schmidely, P. \& Boza, J., 2007. Influence of type of diet on the fat constituents of goat and sheep milk. Small Rumin. Res. 68, 42-63. https://doi.org/10.1016/j.smallrumres.2006.09.017

Sun, X., Henderson, G., Cox, F., Molano, G., Harrison, S.J., Luo, D., Janssen, H.P. \& Pacheco, D., 2015. Lambs fed fresh winter forage rape (Brassica napus) emit less methane than those fed perennial rygrass (Lolium perenee L.) and possible mechanisms behind the difference. PloS One 10(3), 1-16. doi: 10.1371/journal.pone.0119697

Theodorou, M.K., Williams, B.A., Dhanoa, M.S., McAllan, A.B. \& France, J.A., 1994. Simple gas production method using a pressure transducer to determine the fermentation kinetics of ruminants feeds. Anim. Feed Sci. Tech. 48, $185-197$. https://doi.org/10.1016/0377-8401(94)90171-6

Troegeler-Meynadier, A., Nicot, M.C., Bayourthe, C., Moncoulon, R. \& Enjalbert, F., 2003. Effects of pH and concentrations of linoleic and linolenic acids on extent and intermediates of ruminal biohydrogenation in vitro. J. Dairy Sci. 86, 40544063. https://doi.org/10.3168/jds.S0022-0302(03)74017-X

Wang, Y., Jacome-Sosa, M.M. \& Spencer, D.P., 2012. The role of ruminant trans fat as a potential nutraceutical in the prevention of cardiovascular disease. Food Res. Inter. 46, 460-468. https://doi.org/10.1016/j.foodres.2011.08.019

Williams, O.S.R., Moate, J.P., Deigton, H.M., Hannah, C.M., Wales, J.M. \& Jacobs, L.J., 2016. Milk production and composition, and methane emissions from dairy cows fed lucerne hay with forage brassica or chicory. Anim. Prod. Sci. 56, 304-311. DOI: 10.1071/AN15528 